\title{
An evaluation of the prevalence of autoimmunological diseases in patients with diabetes and obesity hospitalized in the Department of Diabetology, Rural Medicine Institute in Lublin
}

GRZEGORZ ROMAN SZCZEŚNIAKA, B, D-G, WOJCIECH ZDYBELE, F, PATRYCJA KOZAK-NURCZYKE, F, PIOTR DZIEMIDOKA, D, F

Department of Diabetology, Rural Medicine Institute in Lublin

A - Study Design, B - Data Collection, C - Statistical Analysis, D - Data Interpretation, E - Manuscript Preparation,

$\mathbf{F}$ - Literature Search, $\mathbf{G}$ - Funds Collection

Summary Background. Type 1 diabetes often coexists with other diseases conditioned autoimmunologically.

Objectives. An assessment of the coexistence of autoimmune diseases in patients with type 1 diabetes in relation to their prevalence in people with type 2, secondary diabetes and obesity without diabetes.

Material and methods. Analysis of the medical records of 937 patients hospitalized in the Diabetology Department: 203 with type 1 diabetes, 583 with type 2,24 with secondary diabetes and 126 obese.

Results. In patients with type 1 diabetes one additional autoimmune disease was found in $44(22 \%)$, two in 7 (3\%) - we diagnosed APS-3 in those cases. In 40 (20\%) of them Hashimoto's thyroiditis was found, in $5(2 \%)$ - Graves' disease, 6 (3\%) - vitiligo, $4(2 \%)$ - Addison-Biermer's disease or celiac disease, in $2(1 \%)$ rheumatoid arthritis. Sjögren syndrome, autoimmune vasculitis and stiff man syndrome we recognized in single men. In the type 2 diabetics two autoimmune diseases were found in 1 patient $(0.2 \%)$ and one in $23(4 \%)$. In the group of obese patients these kinds of diseases were found in 7 cases $(6 \%)$. Among patients with secondary diabetes there were no autoimmune diseases. Hashimoto disease was also the most frequent autoimmune disease in the type 2 diabetes and obesity groups: 17 subjects (3\%) and $6(5 \%)$, respectively.

Conclusions. We should actively look for other autoimmune disease in patients with type 1 diabetes. Also, we cannot forget that they can also occur in patients with type 2 diabetes and isolated obesity.

Key words: obesity, autoimmune diseases, diabetes, Hashimoto's thyroiditis, APS.

\section{Background}

Around $8-10 \%$ off all diabetic patients have type $1 \mathrm{di}-$ abetes. The disease is caused by autoimmune destruction of the beta cells located in the pancreas, which in consequence leads to absolute shortage in insulin supply. The disease is most common in children, teenagers and young adults, although it may be diagnosed later in life as LADA (latent autoimmune diabetes in adults). Regardless of the age at which diabetes was diagnosed, immediate insulin therapy should be implemented as treatment $[1,2]$.

Type 1 diabetes usually affects patients who are genetically predisposed towards it. The HLA (human leukocyte antigens) are most strongly linked to the autoimmune reaction. This genetic predisposition is congenital and is characteristic for other autoimmune diseases. In order for them to manifest, the coexistence of other environmental factors is crucial $[1,3,4]$.

If the immune system mistakenly detects its own tissues as foreign, it may also attack other tissues or organs. Therefore, different autoimmune diseases may present in pairs or larger groups, leading to a diagnosis of autoimmune polyglandular syndrome, otherwise known as APS. Knowing the fact that many such diseases may present with no symptoms, it is recommended that the patient be monitored for them. Meanwhile, the presence of an autoimmune disease in a pa- tient with an unclear type of diabetes may suggest an insulin dependent type of the disease e.g. LADA $[1,5]$.

\section{Objectives}

The aim of this study was to evaluate the coexistence of autoimmune diseases in patients with type 1 diabetes in relation to their occurrence in patients with type 2 diabetes, secondary diabetes and obesity without diabetes mellitus.

\section{Material and methods}

An analysis of archived 937 randomly chosen digital "discharge abstracts" of patients hospitalized in the Clinic of Diabetology, Institute of Agrarian Medicine in the years 2008-2015 was performed. Among the studied group 203 patients $(22 \%)$ were diagnosed with type 1 diabetes, 583 (65) with type 2 diabetes, 24 (3\%) with diabetes as a result of chronic or acute pancreatitis, and $126(13 \%)$ of the patients were obese without diagnosed diabetes. The diagnosis of autoimmune diseases was based on interviews conducted earlier, and active searches for symptoms during hospitalization. All patients underwent a thorough physical examination. In patients not previously diagnosed, anti-TPO, anti-TG and TTGA IgA and IgG, as well as anti-endomysi- 
um antibodies with TSH level and vitamin $\mathrm{B}_{12}$ levels were tested. In patients with a low level of TSH or symptoms of Graves Basedow disease, tests for anti-TSH antibodies were also performed. In patients with an elevated titre of anti-TPO and/or abnormal level of TSH, the diagnostics was supplemented with free fraction thyroid hormone tests, and in those patients in whom anti tissue transglutaminase titre was elevated additional gastroscopy with duodenal mucosal sampling was performed. In patients with a lowered level of vitamin $B_{12}$, intrinsic factor antibodies (anti-IF) titres were determined. When symptoms of other autoaggressive diseases occurred, appropriate diagnostic tests were performed, e.g. anti-cyclic citrullinated peptide autoantibody testing (anti-CCP) if rheumatoid arthritis was suspected, or anti-neutrophil cytoplasmic antibodies (ANCA) when autoimmune vasculitis was suspected.

The Chi-square NW test was used for statistical analysis, statistical significance $p<0.05$.

\section{Results}

In the group of patients with type 1 diabetes the following was concluded: 1 additional auto immunological disease in 44 patients $(22 \%), 2$ in seven women $(3 \%)$ - APS-3 was diagnosed in all patients. In 40 patients that belonged to the group (20\%; 29 (29\%) women and $11(11 \%)$ men $p<0.001)$ Hashimoto thyroiditis was diagnosed, in $5(2 \%)$ - Grave's disease, in $6(3 \%)$ - vitiligo in $4(2 \%)$ - pernicious anemia, in $4(2 \%)$ - celiac disease, and in $2(1 \%)$ - rheumatoid arthritis. Sjogren's syndrome, autoimmune vasculitis and stiff-man syndrome was diagnosed in several patients.

In the group of patients with type 2 diabetes, two autoimmune diseases were diagnosed in 1 person $(0.2 \%)$ and one in $23(4 \%)$. In the group of obese patients such diseases were detected in 7 people $(6 \%)$. In patients with secondary diabetes no autoimmune diseases were detected. In patients with type 2 diabetes and obesity, the most common autoimmune disease was also Hashimoto's thyroiditis, which was detected in $17(3 \%)$ and $6(5 \%)$, respectively. Vitiligo was present in 4 patients with type 2 diabetes $(0.7 \%)$ and in one patient with obesity $(0.8 \%)$. Two patients with type 2 diabetes also had rheumatoid arthritis, and one had autoimmune hepatitis. Erythema nodosum was diagnosed in one patient with type 2 diabetes.

\section{Discussion}

Type 1 diabetes was most commonly coexistent with autoimmune diseases. This is quite logical since it develops on the same basis. Nonetheless, it cannot be said that such diseases are not seen in patients with type 2 diabetes and obesity.

Common comorbidity of autoimmune diseases in patients with type 1 diabetes, as well as in their families, has been proven in numerous research studies. One good example is Goworek et al. [6], where the coexistence of one autoimmune disease in $26.9 \%$ of patients with type 1 diabetes was shown. $17.35 \%$ of patients were diagnosed with Hashimoto's thyroiditis, although it was significantly more common in women than in men. Other diseases according to frequency: vitiligo, celiac disease, rheumatoid arthritis and alopecia areata. In several cases Sjögren syndrome, colitis ulcerosa and autoimmune hepatitis were also diagnosed. Type 1 diabetes was diagnosed in first- and seconddegree relatives in over $14 \%$ of studied patients. Relatives of $16 \%$ of researched type 1 diabetes patients were diagnosed with other autoimmune diseases, i.e. rheumatoid arthritis, alopecia areata, psoriasis, vitiligo, Hashimoto's thyroiditis and celiac disease.
Kahaly and Handsen report that $15-30 \%$ of patients with type 1 diabetes were diagnosed with autoimmune thyroiditis (Hashimoto's or Grave's), 5-10\% with atrophic gastritis and/ /or pernicious anemia, 4-9\% with celiac disease, 2-10\% - vitiligo, 0.5\% with Addison's disease. They also show that in more than $1 / 3$ of those patients APS may also develop [7].

The presence of antigen antibodies for a longer time may anticipate clinical symptoms of the disease. In the prediabetes stage, systemic antibodies may be detected, e.g. thyroid peroxidase antibodies, tissue transglutaminase antibodies [8].

Both in our research as well as in other reports, chronic thyroiditis presented together with type 1 diabetes [9]. It is probably caused by a mutual genetic predisposition in the range of the HLA system [10]. Factors of autoimmune disease probability in patients with type 1 diabetes are: female gender, older age, puberty, iodine rich diet, late diagnosis of diabetes, longer duration of diabetes, positive titre of antithyroid antibodies, other autoimmune diseases, and family history of disease. The presence of elevated thyroid antibody titre in the population of children with diabetes mellitus is reported in 10-32\%, and thyroid diseases are present in $10-30 \%$ [9] of cases. Apart from Hashimoto's thyroiditis, another quite common autoimmune disease of the thyroid presenting in patients with type 1 diabetes is Grave's thyroiditis, reported in $2 \%$ of our studied group.

Because of the common coexistence of diabetes and thyroid function abnormalities, the Polish Society of Endocrinology and Polish Society of Diabetology created (in 2013) a series of recommendations regarding screening tests for thyroid function abnormalities in types 1 and 2 diabetes. It is recommended that for all patients who were not tested earlier, with recently diagnosed diabetes mellitus and in patients with a history of the disease, thyrotropin levels should be assessed. In patients with type 1 diabetes both TSH and anti thyroperoxidase antibodies should be tested. On the other hand, however, in cases with type 2 diabetes, antiTPO should be tested when TSH concentration is larger than or equal to $2.0 \mathrm{mIU} / \mathrm{L}$. In patients with elevated antibody titers, anti-TPO levels should be test once a year in cases with type 1 diabetes and every two years in type 2 .

As long as Grave's disease presents with clear symptoms, the symptoms of Hashimoto's thyroiditis, on the other hand, can be quite puzzling. When most of the thyroid is destroyed in the course of the disease, clinical symptoms manifest analogically to type 1 diabetes. Suspicion of Hashimoto's disease can be suggested by atypical clinical symptoms, such as difficulty in balancing the metabolism of diabetes, reduced daily insulin requirement, a higher incidence of hypoglycemia, slow growth rate in children, iron deficiency anemia, delayed puberty, bradycardia, painless goiter, a feeling of constant fatigue and cold, or problems with learning and concentration [9].

According to a Taiwanese study, the incidence of general autoimmune diseases of the thyroid gland in patients with type 1 diabetes is 6.65 times higher than in people without diabetes, of simple goiter -2.74 times higher, hyperthyroidism thyroid - 6.95 times higher, hypothyroidism - 6.54 times higher, inflammation of the thyroid - 16.07 times higher, and inert nodular goiter - not significantly higher [12].

Apart from thyroid disease in our study with type 1 diabetes vitiligo, pernicious anemia and celiac disease most commonly coexisted, which can complicate the treatment of diabetes and requires attention. It is estimated that celiac disease is present in $1.0-10.4 \%$ of patients with type 1 diabetes, depending on the age of the population and the applied diagnostic methods. Most people with diabetes type 1 and celiac disease carry the HLA-DQ2 antigens. Among people possessing two alleles coding the same antigen (homozygotes), the probability of developing celiac disease amounts 
to $33 \%$ [13]. Celiac disease adjoining in the course of type 1 diabetes may cause a reduction of the need for insulin with a tendency to hypoglycemia. Other symptoms suggesting celiac disease in patients with type 1 diabetes include: weight deficiency, short stature, delayed puberty (especially in boys), recurrent abdominal pain, abnormal stools, anemia hypochromic, and irritability. The necessity to perform periodic screening for celiac disease (primarily the determination of antibodies against tissue transglutaminase - the most sensitive parameter) in patients with type 1 diabetes is very important. It has been proved that the survival rate with undiagnosed and untreated celiac disease is smaller by nearly one-quarter $[8,13]$.

In type 2 (DM2), compared to DM1 autoimmune diseases are much less frequent. This is due to its pathogenesis, which is influenced primarily by insulin resistance, and not by a faulty immune system. Interestingly, there is evidence that obesity itself may contribute to the development of autoimmune diseases. Professor Shoenfeld's research from Tel Aviv University suggests that it might lead to impairment of the autotolerance of the immune mechanisms (the immune system does not respond to host-antigens present in normal tissues), which provides the basis for the development of such diseases and generates a pro-inflammatory environment that can complicate the treatment. It has been shown that the main causative agents are adipocytokines, i.e. compounds secreted by fatty cells, and are involved, among others, in an immune response, such as leptin, adiponectin, resistin and visfatin. It was observed that adipocytokines are involved in the pathogenesis of diseases such as rheumatoid arthritis, systemic lupus erythematosus, multiple sclerosis, inflammatory bowel disease, type 1 diabetes, psoriasis, psoriatic arthritis, and Hashimoto's thyroiditis [14].

The prevalence of autoimmune diseases estimated in our work is certainly not an accurate picture of all patients with diabetes and obesity in our country. It refers to a specific group of patients who required hospitalization in the Department of Diabetology IMW in Lublin. The study is retrospective in nature, and the diagnostics were not previously planned for epidemiological analysis. It is based on standard practice in our department. Diagnoses made before hospitalization were not verified.

Finally, it is worth noting that the prevalence of related autoimmune diseases is increasing $[9,13]$, so the meaning of the dependencies described above may also be increasing in importance.

\section{Conclusions}

Among the patients hospitalized in the IMW Clinic of Diabetology, autoimmune diseases exist significantly more often in patients with type 1 diabetes than in other groups. They are diagnosed in around $25 \%$ of patients in that group. The most common autoimmune disease, apart from type 1 diabetes, is Hashimoto's thyroiditis, which is diagnosed in type 1 diabetes in $20 \%$ of cases ( 3 times more common in women). In $3 \%$ of patients (mainly women) with type 1 diabetes hospitalized in the clinic, autoimmune polyendocrine syndrome type 3 is diagnosed.

Patients with type 1 diabetes should be actively tested for other autoimmune diseases. It must also be remembered that they may also be present in patients with type 2 diabetes and isolated obesity.

Source of funding: This work was funded by the authors' resources.

Conflict of interest: The authors declare no conflict of interests.

\section{References}

1. Sieradzki J. Cukrzyca. In: Gajewski P, ed. Interna Szczeklika 2014. 6th ed. Kraków: Medycyna Praktyczna; 2014: 1353-1400.

2. Rother K. Diabetes treatment - bridging the divide. N Engl J Med 2007; 356(15): 1499-1501.

3. Strojek K. Diabetologia - praktyczny poradnik. 3rd ed. Poznań: Termedia; 2014.

4. Witek P, Witek J, Pańkowska E. Choroby autoimmunologiczne w cukrzycy typu 1 - badania przesiewowe, diagnostyka i leczenie. Med Wieku Rozw 2011 [cited 01.04.2016]. Avaible from URL: http://www.medwiekurozwoj.pl/articles/2012-1-4.html.

5. Stenstrom G, Gottsater A, Bakhtadze E, et al. Latent autoimmune diabetes in adults. Definition, prevalence, $\beta$-cell function, and treatment. Diabetes 2005; 5(Suppl. 2): 68-72.

6. Goworek M, Madej A, Suwała S, et al. Występowanie chorób autoimmunologicznych u osób z cukrzycą typu 1 i ich krewnych Diabetol Klin 2013; 2(1): 9-13.

7. Kahaly G], Hansen MP. Type 1 diabetes associated autoimmunity. Autoimmun Rev 2016 [cited 01.04.2016]. Avaible from URL: http://www.sciencedirect.com/science/article/pii/S1568997216300441.

8. Otto-Buczkowska E, Jarosz-Chobot P, Minkina-Pędras M, et al. Współwystępowanie chorób autoimmunologicznych z cukrzycą typu 1 u młodocianych chorych w oparciu o dane piśmiennictwa i obserwacje własne. Prz Lek 2008; 65(3): 140-144.

9. Korzeniowska K, Myśliwiec M, Balcerska A. Autoimmunologiczne zapalenie tarczycy u dzieci z cukrzycą typu 1. Diabetol Prakt 2010; 11(3): 89-93.

10. Barker JM, Yu J, Yu L, et al. Autoantibody 'subspecificity' in type 1 diabetes. Diabetes Care 2005; 28(4): $850-855$.

11. PTD: Zalecenia kliniczne dotyczące postępowania u chorych na cukrzycę. Diabetol Klin 2016; 5(Supl. A): A67.

12. Ming-Chi L, Shou-Chih $\mathrm{C}$, Kuang-Yung $\mathrm{H}$, et al. Higher risk of thyroid disorders in young patients with type 1 diabetes: a 12-year nationwide, population-based, retrospective cohort study. PLoS ONE 2016; 11(3): e0152168, doi: 10.1371/journal. pone.0152168.

13. Jarosz-Chobot P. Celiakia u chorych na cukrzycę typu 1. Diabetologia Online [cited 01.04.2016]. Avaible from URL: http:// diabetologiaonline.pl/lekarz_diabeto_adoz,info,291,0.html.

14. Versini M, Jeandel PY, Rosenthal E, et al. Obesity in autoimmune diseases: not a passive bystander: Autoimmun Rev 2014; 13(9): 981-1000.

Address for correspondence:

Grzegorz Szcześniak, MD, PhD

Klinika Diabetologii IMW

ul. Jaczewskiego 2

20-090 Lublin

Polska

Tel.: +48 81 718-44-77

E-mail: grzeszcze@poczta.wp.pl

Received: 10.04.2016

Revised: 30.05.2016

Accepted: 10.06.2016 